\title{
An Empirical Study of Stereotyped Images of China in American Media
}

\author{
Jianqing $\mathrm{Wu}$ \\ School of Foreign Languages, Qingdao University of Science and Technology, Qingdao, China \\ Email: wjq58@ hotmail.com
}

\begin{abstract}
The image of a country, like that of a person, is supposed to be recognized as a positive one while often stereotyped. The paper firstly explains what image and China's National Image are. Based on these, the term stereotyping is led in. In order to prove this, two examples of hot topics related to stereotyped image of China in U.S. media are given. They are China's One Child Policy as well as Tibet Issue and Xinjiang Riot. As the body, the paper further discusses the birth control policy which discourages people from producing more than one child; in addition, it speaks about the status quo and the history of Tibet and Xinjiang and what Chinese government has been doing in the two zones. Subsequently, three reasons of stereotyping are illustrated before the suggested solutions and conclusion are given finally.
\end{abstract}

Index Terms - China, stereotyped image, U.S. media, One Child Policy, Tibet Issue and Xinjiang Riot

\section{INTRODUCTION}

This paper mostly uses CNN and NYT as the example of American media. CNN is one of the representatives of Electronic media and NYT is one of the representatives of national wide newspaper.

The image of a person needs to be recognized as a positive one. So are countries which are made up of people and run by political elites. Historically speaking, political leaders have recognized that images matter. They have tried to promote favorable characters and get rid of unfavorable stereotypes of themselves. China's leaders are no exception.

But the people of any country are exposed to the media and naturally are affected and even induced to think of certain images in certain ways. The public has the right to be shown the fact about the people and image of another country to improve the international image of that country and to stop negative stereotyping.

\section{A. What is Image}

An image, as Rubinstein (1980) defined it, "is a message that is sent one individual or group to another." If a country is defined by the American media as a "rogue" state, chances are this country is isolated.

The image of one nation in another is determined greatly by the opinion of their leaders. The majority of people have no chance to personally see what a foreign nation is like, but they see images of these countries in the media. Ever since 1989, China's negative image in the U.S. media has been a hot topic of concern. Why?

The American media had been trying to "demonize" China by deliberately focusing on the negative side. The American media practitioners, however, denied that they had intentionally done anything to demonize China. They argued that the U.S. media's China coverage had been fair and normal enough. The debate starts from these two different viewpoints (Pan, 2003).

\section{B. What is China's National Image}

The Chinese government has tried to build the following images of China in international affairs: a peace-loving country, victim of foreign aggression, socialist country, bastion of revolution, anti-hegemonic force, developing country, major power, international cooperator (Wang, 2003).

Wang's research (2003) illustrates the following with figures. Americans share the view that China is a communist country. Americans generally agree with China's projected images of itself as a developing country and major power. Americans sometimes view China as exhibiting opposing hegemonic behaviors, but more often they see China as engaging in hegemonic behaviors. They sometimes view China as a victim of foreign aggression, but more often see China as victimizing its own neighbors. China portrays itself as a peace-loving nation, international cooperator, while Americans think exactly the opposite. According to the data here, they have never seen China as peace-loving. Instead, they frequently regard China as militant. Why are American images of China sometimes similar to, but often at odds with China's projected images?

Objectively speaking, China's economical backwardness and low living standards are the key elements to indicate its development status. While if judged subjectively, other images are thus more controversial such as anti-hegemonic force, peace-loving nation, and autonomous actor are more subjective subjects.

\section{ON STEREOTYPING}


Before defining stereotyping, let's look at a classical example:

Jack Cafferty, the CNN anchor, abused Chinese in his program:

"Well, I don't know if China is any different, but our relationship with China is certainly different. We're in hock to the Chinese up to our eyeballs because of the war in Iraq, for one thing. They're holding hundreds of billions of dollars worth of our paper. We also are running hundred of billions of dollars worth of trade deficits with them, as we continue to import their junk with the lead paint on them and the poisoned pet food and export, you know, jobs to places where you can pay workers a dollar a month to turn out the stuff that we're buying from Wal-Mart. So I think our relationship with China has certainly changed. I think they're basically the same bunch of goons and thugs they've been for the last 50 years." (Cafferty, 2008). On May 15, 2008, according to Chinese Foreign Ministry spokesman Qin Gang, CNN President Jim Walton sent a letter to Zhou Wenzhong, Chinese ambassador to the United States: "On behalf of CNN I'd like to apologize to the Chinese people for that. CNN has the highest respect for Chinese people around the world and we have no doubt that there was genuine offense felt by them over the Jack Cafferty commentary." CNN, however, denies that an apology to the Chinese government was ever made, stating that it was meant for the Chinese people alone. So the China image of CNN was obviously stereotyped. Although the apology was made, the bad consequences had been created because of the power of media. That's why they prefer to risk stereotyping at the least cost of making an apology.

We can see segment of a whole from the above. The word stereotyping was first used by journalist Walter Lippmann (1922) in his classic Public Opinion to describe judgments made about others on the basis of their ethnic group membership. Today, the term is more broadly used to refer to negative or positive judgments made about individuals based on any observable or believed group membership.

"Stereotypes are unconscious habits of thought that link personal attributes to group membership. Stereotyping is an inevitable concomitant of categorization: As soon as an observer notices that a "target" belongs to a stereotyped group (especially an out-group), characteristics that are stereotypically linked to the group are activated in the observer's mind." (Reskin and Mcbrier, 2000).Stereotyping is a cognitive component, a set of beliefs about a distinguishable group, wherein particular traits are thought to be characteristic of the entire group. They reflect beliefs what we think EVERY member of that group are like.

Statistically, at least one source has stated that more than $90 \%$ of media content disseminated by the western media headed by the US. More than $70 \%$ are spread from the transnational media in the west. The western media headed by the US control the discourse hegemony around the globe,hence, the stereotyping will continue fermenting in it (Wang, 2003).

There are many studies about this issue. T. Christopher Jespersen in his book American Images of China, 1931-1949 attempts to explain why Americans throughout their history have viewed China, in part, with "naivete, paternalism, and awe."(Craft, 1996). China has been a named cottage industry and its fast rapid development has rehashed the old debate of why Americans and their leaders have consistently misperceived China.

Among the media to study for example of this stereotyping, besides CNN, "The New York Times" is essential. As the most prominent American newspaper, "The New York Times" has always self-claimed to be open-minded, objective and fair. It embraces the well-known motto "All The News That's Fit to Print", which is also printed on the front page as a masthead logo dating back to 1896.

However, there are still mounts of criticism, alleging that NYT, in the coverage of China, focuses only on the negative aspects of China. There seems to be two-sides of the portrayal of China's Image, Truth or Bias? I believe that on one hand, there is no persuasive, systematically gathered evidence to show that the U.S. media has been conspiring to demonize China. But on the other hand, we oughtn't to ignore that national interest as well as the media's critical nature predispose its negative inclination in covering China and may distort China's image (sina, 2009).

\section{Two EXAmples OF Hot Topics RELATED to CHINA STEREOTYPED IMAGE IN U.S. MEDIA}

\section{A. China's One Child Policy-The Birth Control Policy Discourages People from Producing More than One Child.}

China's one child policy which limits couples to one child was established by Chinese leader Deng Xiaoping in 1979 to limit China's population growth. Although designated a "temporary measure," it continues a quarter-century after its establishment. China will not consider changing its one-child policy for at least a decade for fear that a population surge could spark social and economic instability. The policy has prevented an additional 400 million births. China's population currently stands at 1.3 billion, growing 16 to 17 million annually.

On the other hand, it is not an all-encompassing rule because its limit actually applies to only a portion of the population who are ethnic Han Chinese living in urban areas. Citizens living in rural areas and minorities living in China are not subject to the law. Since rural couples are allowed up to two if their first child is a girl. The country's ethnic minorities are also exempt from these rules. This rule has caused a disdain for female infants to be like abortion, neglect and even abandonment which will result in the disparate ratio of 114 males for every 100 baby females under four. It is normal to be 105 males to 100 females.

Nonetheless, statistically, China's total fertility rate (the number of births per woman) is 1.7 , much higher than slowly-declining Germany at 1.4 but lower than the U.S. at 2.1 (2.1 births per woman is the replacement level of fertility, representing a stable population). 
Some media are very responsible for their reports. CNN's Ted Turner says Chinese one-child policy is not draconian. However, some non-mainstream media like Internet sources seem to be very negative on this case, not a blog is provoking. For example, Smeaton (2009) in his blog, wrote, the Chinese regime's 30-year record of infanticide, forced abortion, forced sterilization, torture, imprisonment and other crimes is so voluminous that Turner's comments are analogous to denying the Holocaust.

In a 28 -word sentence, Smeaton used 8 acrimonious and very draconian wordings like regime, infanticide, forced, sterilization, torture, imprisonment, crimes and Holocaust.

Still, some others think that the one child policy is no respect the rights of the individual, but culturally, now in many Chinese's idea, the rights of the society collectively should prevail over the personal decisions. Many people know that China is an overpopulation country and it is the most populous country in the world. It has 1.3 billions people now. And it will be 1.5 billions people until 2033. It will be the summit population at that time. If it were not controlled, there would be a population explosion which may endanger beyond China.

In a word, the China's one child policy is a population control success since it is fit for China' situation. China is farseeing and responsible for her descendants.

\section{B. Tibet Issue and Xinjiang Riot}

a. China's status quo and Tibet history

China is not a single Ethnic nation, in fact, 56 ethnic groups make up China, including Han, Mongols, Koreans, Muslim, Tibetans etc. They are united as Chinese, so, in other words, China is just as multicultural as many countries.

Some solid facts can show why Tibet was, is, and always will be a part of China. Tibet has been a part of China for thousands of years. This is the "Legitimacy" as well as the fact.

What Chinese government has been doing in Tibet:

In 1903, due to the weak Qing Dynasty, British gained control over Tibet as a colonial region and treated them as slaves. In 1950 when Chinese regained Tibet, Tibet was still in a slavery society under Dalai Lama's puppet regime. The Chinese government spends 200 million Yuan (40 million US Dollars) a year developing Tibet, building schools, hospitals, infrastructures and etc.

Western news media like CNN would like to attack other countries' sovereignty and some governments never stop trying to split other countries apart. Nobody wants their home country to break it apart. CNN referred to Tibet as a "country." CNN's policy is to refer to Tibet as "Tibet Autonomous Region of China." Ironically, CNN's reputation is based on reporting global news accurately and impartially.

The coverage of CNN is pro-separatism, seeming that the Tibetan people are being oppressed. They are the products of their culture and their anti-communism. It still has a potential "cold-war" mentality.

b. Xinjiang Riots:

About Xinjiang:

The Xinjiang Uygur Autonomous Region (XUAR) is a largely Muslim area in the far northwest of China. In area it is the largest province-level unit in China, accounting for about one-sixth of China's total area. The most populous ethnic group is the Uygurs, after whom the XUAR is named. The Uygurs are Turkic ethnically and culturally, and strong adherents of Islam (Mackerras, 2001).

\section{July 5 Riots:}

The blood-thirsty maiming and slaughtering of civilians, as young as six years old, in Urumqi on July 5, is heinous homicide, barbarity against humanity, and terrorist act on China. They really did something "big": Up to 160 civilians were killed, and hundreds more seriously injured. The barbarity has astonished China and the world.

"Although the key July 5 reports by foreign media have improved to some extent, bias in the reporting still exists," said Phoenix Satellite Television commentator Lawrence Ho (2009).

The New York Times were found to be using real pictures with inaccurate captions. bbs.chinadaily (2009) tells a story: A New York citizen named Janet who grew up in Xinjiang commented in response to a New York Times report describing a "peaceful demonstration." "Does this mean lives are not important? If your wife or husband was killed, could you still call it "peaceful demonstrations?" Janet said. "The New York Times should do more research and not release this kind of false report.

Like Bin Laden who wanted the United States on fire and in ruins, the masterminds and ringleaders of "July-5" killings, hidden in China and abroad, are dreadful of and loath a strong and unified China. Like "September 11" to Americans, "July 5" will serve as a reminder to all Chinese people. The government must be ready and steadfast in a heightened alertness to combat fanaticism and terrorism, all the time. Meanwhile, China's anti-terrorism efforts ought to integrate with world's collective anti-terror regime to terminate terrorist financing, and rid it off (Li, 2009).

I might add, the criminals that CNN is speaking up for in Xinjiang unfortunately do not represent the Uyghur people. Actually, the people are honest and peace-loving in nature.

\section{THE REASONS OF STEREOTYPING}

A. The Enmity Sentiment towards Communism.

Western media attention is usually paid to China's political system and its record on human rights. The U.S. 
journalists tend to ascribe all China's problems, political, economic, and social, to China's communist system, a system that the American media dislike. On the subject like Chinese political system, Chinese economic reform, human rights, the Taiwan Issue, or Tibet, west media believe that the United States can "teach" China how to do it (Pan, 2003). The negative image fits well with the American stereotype of communist countries. The biases of China on the American media are just short of saying they hate China, their prejudice towards China is no less than those that openly admit it.

\section{B. Cultural Difference, Especially in Religious Belief}

Although research now shows religion has less and less influence in American life, it is still the dominant value of the American society which is determined by its culture, especially on the "Bible Belt". Among them, to some degree, the Americans' sense of being God's chosen people and the related concept of "manifest destiny" have greatly influenced American view of China and other countries. In the past 200 years of history of U.S.-China contact, China has been despised as a place of "heathens" or "pagans". This view is still popular today among many American media, especially because of the "alien" political system China has now (Pan, 2003).

\section{Due to American National Character: Sense of Calling and Being More Concerned about Other Countries}

American media show us the dominant assumptions held by the mainstream American society about China: Judge China with American standard, interrupt China domestic affairs with the excuse of being concerned of their freedom and democracy. Actually, no country is numb; they all are concerned about the happiness of their people.

\section{The Suggested Solutions ANd CONCLUSION}

American media MUST get rid of its inherent stereotyping to change this stereotype on China. It's a pity to see that the American media like CNN hasn't realized the strength of Chinese public so far, and still take it for granted that all anti American media activities are supported and sponsored by Chinese government. They stereotype again. They underestimate Chinese people, which misleads them to a wrong direction.

It is also a valuable lesson for the American media to move towards a balanced and professional approach to journalism since the people of the world deserve a truthful, trustworthy, and intelligent reporting of events. The audiences need to be rightly informed. Before releasing the news, it is advisable do more research if it is uncertain so as not to mislead the readers or audiences. Otherwise, it will not only cheat the people but also hurt their feeling including the people in the news.

Educate the readers, to hear all parties, not to fix their eyes on the shadowy parts of China that the media has provided. Give an ear to more voices. China has more sunshine. Report China in a more tolerating way, not choosing to be negative. We all like a harmonious world.

Put oneself in someone's shoes and have a transposition, some reporters in the U.S. media are not anti-Chinese. For example, Nicholas Kristof of the NYT reported from and lived in China for years. His writings are widely read and he is definitely NOT anti-China. But some do not. Jack Cafferty of the CNN and the bloggars like John Smeaton refuse to understand something from other's perspective, they prefer to think in their own American way.

All China can do really is keep cautious and counter the Western propaganda with educated and understandable political education.

\section{ACKNOWLEDGEMENT}

This paper is financed by Humanities and Social Sciences Fund of Qingdao of University of Science and Technology in 2009 , the project number is $09 \mathrm{XB} 08$.

\section{REFERENCES}

[1] bbs.chinadaily. (2009). July 15, 2009

http://bbs.chinadaily.com.cn/viewthread.php?gid=2\&tid=641524\&extra=page\%3D1\&page=2.

[2] Cafferty, Jack. (2008). CNN, September 26, 2008, www.cnn.com.

[3] Craft, Stephen G. (Tunghai University). (1996). H-PCAACA (Sept. 1996) Review of American Images of China, 1931-1949. by Jespersen, T. Christopher. 1996, Stanford, Calif.: Stanford University Press, xx +254 pp.

[4] Ho, Lawrence. (2009). From riot in Tibet to Xinjiang: Western media's bias against China continues, People's Daily Online. Published on July 10, http://bx.businessweek.com/satellite-television/from-riot-in-tibet-to-xinjiang-western-medias-biasagainst-china-continues/4297752858623203702-0550fc607e0b6fd6be3f8f05929586fb/

[5] Li, Hong. (2009). Urumqi killing is barbaric,11:29, July 10, 2009, People's Daily Online, http://english.people.com.cn/90002/96743/6697878.html.

[6] Lippmann, Walter. (1922). Public Opinion. New York: Macmillan.

[7] Mackerras, Colin. (2001). Xinjiang at the turn of the century: the causes of separatism. Central Asian Survey, 20(3): 289-303.

[8] Pan, Zhigao. (2003). An Analysis of China's Image in the New York Times: 1993-1998. Kai Feng: Henan University Press.

[9] Reskin, Barbara F.; McBrier, Debra Branch. (2000). American Sociological Review, 65(2): 210-233.

[10] Rubinstein, Murray A. (1980). The Northeastern Connection: American Board Missionaries and the Formation of American of Opinion Toward China: 1830-1860, p434, Collected Papers of Modern History Research Center in Academia Sinica, Taiwan. Issue 9. 1980. 
[11] Sina.com. (2009). China's Image: Truth or Bias?--A case study of an editorial by The New York Times from the perspective of national interest, http://blog.sina.com.cn/huye198886.

[12] Smeaton, John. (2009). CNN's Ted Turner says Chinese one-child policy is not draconian, Tuesday, 12 May 2009 , http://spuc-director.blogspot.com/2009/05/cnns-ted-turner-says-chinese-one-child.html.

[13] Wang, Hongying. (2003). National Image Building and Chinese Foreign Policy. China: An International Journal 1(1): 46-72

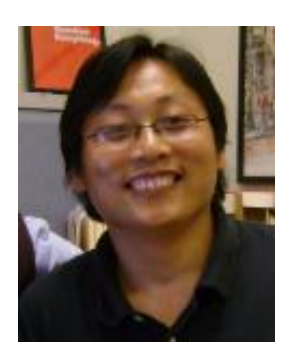

Jianqing Wu was born in Shandong, China in 1971. He earned his master's degree of Social Science (Linguistics) in Shandong University, China in 2003.

$\mathrm{He}$ is an associate professor of Linguistics and Journalism in Qingdao University of Science and Technology, Shandong, China. He has been working in QUST for over 15 years. In 2009, he was financed by Chinese government to do his research in MTSU, U.S.A. In the recent decade, he has published 30 articles and 15 books. Some of them are below: Evaluation in Media Discourse Analysis of a Newspaper Corpus. Journal of Quantitative Linguistics (SSCI, Netherland), 2010. 3: 256-260; Mini Discourse Training-Review on Discourse Analysis 2nd edition. Contemporary Foreign Language Research (CN), 2010. 4: 58-60; The Analysis of Cultural Gaps In Translation and Solutions. English Language Teaching (Canada). 2008: 2. "ENGLISH DEBATE", China Science and Culture Press, Feb. 2003, author; "JOURNALISTIC ENGLISH", Defense Industry Press, Aug.2005, author; "Practical College English Grammar", China Commerce Press, Aug.2002, co-author. His Current and previous research interests are discourse analysis, pragmatics and sociolinguistics.

Prof. Wu is a member in professional societies like the Newspaper In Education Research Society (NIE) -China, IQLA, ELT-China, AILA-China as well as Association of China's Sociolinguistics (ACS). 